Journal of Applied Pharmaceutical Science Vol. 6 (08), pp. 127-134, August, 2016

Available online at http://www.japsonline.com

DOI: $10.7324 / J A P S .2016 .60820$

ISSN 2231-3354 (cc) EY-NC-SA

\title{
Tocotrienol-rich Palm Oil Extract Induces NAD(P)H:quinone Oxidoreductase 1 (NQO1) Expression in Mice Liver
}

\author{
Ahmed Atia ${ }^{1,2}$, Nadia Alrawaiq ${ }^{1}$, Azman Abdullah $^{1 *}$ \\ ${ }^{1}$ Department of Pharmacology, Faculty of Medicine, Universiti Kebangsaan Malaysia Medical Centre (UKMMC), Jalan Yaacob Latif, Bandar Tun Razak, \\ 56000 Cheras, Kuala Lumpur, Malaysia. ${ }^{2}$ Department of Anaesthesia and Intensive Care, Faculty of Medical Technology, Tripoli University, Tripoli, \\ Libya.
}

\begin{tabular}{l} 
ARTICLE INFO \\
\hline Article history: \\
Received on: 22/03/2016 \\
Revised on: 19/04/2016 \\
Accepted on: 05/05/2016 \\
Available online: $30 / 08 / 2016$ \\
\hline Key words: \\
gene expression, NQO1, \\
palm oil, tocotrienol rich \\
fraction, vitamin E.
\end{tabular}

\begin{abstract}
A diet rich in tocotrienols has been shown to be beneficial for health. However, its detailed mechanism of action is still not fully understood. $\mathrm{NAD}(\mathrm{P}) \mathrm{H}$ :quinone oxidoreductase 1 (NQO1) is important in cellular defence due to its ability to detoxify reactive quinones and quinoneimines to their less toxic hydroquinones forms. The objective of this study is to investigate the effects of different doses of palm oil-derived tocotrienol rich fraction (palm TRF) supplementation on NQO1 gene and protein expression in mice livers. Western blot and qPCR assays were used to detect NQO1 expression levels. It was found that palm TRF significantly induced NQO1 expression at all doses given. In conclusion, palm TRF treatment increased NQO1 gene and protein expression in mice liver dose dependently, with the highest expression seen in mice treated with $1000 \mathrm{mg} / \mathrm{kg}$ palm TRF, followed by 500 and $200 \mathrm{mg} / \mathrm{kg}$ respectively.
\end{abstract}

\section{INTRODUCTION}

Vitamin $\mathrm{E}$ is an interesting group of compounds with diverse biological effects. It is widely accepted to be the first line of antioxidant defence against lipid peroxidation, protecting polyunsaturated fats in cellular membranes through its freeradical scavenging activity at the early stages of free radical attack (Niki, 2015). A total of eight different isoforms of vitamin E that belongs to two groups are known to occur in nature; $\alpha, \beta$, $\gamma, \delta$ tocopherols and $\alpha, \beta, \gamma, \delta$ tocotrienols. These compounds are characterized by a 6-chromanol ring structure and an isoprenoid side chain (Colombo, 2010). An isolated fraction of palm oil that consists mainly a mixture of $\alpha, \gamma, \delta$-tocotrienols and some $\alpha$ tocopherols is commonly known as "tocotrienol rich fraction" (TRF) (Valk and Hornstra, 2000). Most of the tocopherols have saturated side-chains, whereas tocotrienols side chains possess double bonds at the 3', 7', and 11' positions (Figure 1).

\footnotetext{
* Corresponding Author

Email: manlah1969@yahoo.com
}

Tocotrienols make up a major part of total vitamin E content in several food sources e.g. palm oil, rice bran and annatto (Atia and Abdullah, 2013).

All eight isomers of vitamin $\mathrm{E}$ are absorbed from the intestine, transported by chylomicrons in lymph, and then incorporated into hepatic cells. Both tocopherols and tocotrienols undergo omega oxidation, followed by beta oxidation. The metabolism rate of vitamin $\mathrm{E}$ is highest for tocotrienols and lowest for tocopherol, further suggesting on the tocotrienols' stronger biological effects (Atia and Abdullah, 2014).

Vitamin E has been given a thorough consideration as an important component of the antioxidant network. As such, it is assumed to prevent cells from potentially dangerous by-products of metabolism such as reactive oxygen species (ROS) (Colombo, 2010). All forms of vitamin $\mathrm{E}$ have antioxidant activity, however, tocotrienols exert enhanced antioxidant activities compared to tocopherols (Vasanthi et al., 2012). In addition, tocotrienols have other significant functions, particularly in maintaining a healthy cardiovascular system and a potential role in protection against cancer and other diseases (Ling et al., 2012). 
$\mathrm{NAD}(\mathrm{P}) \mathrm{H}$ : quinone oxidoreductase 1 (NQO1) is a cytosolic enzyme that catalyses two- or four-electron reduction of many endogenous and environmental quinones using flavin adenine dinucleotide (FAD) as a cofactor. This enzyme is generally considered as a detoxification enzyme due to its ability to detoxify reactive quinones and quinone-imines to their less reactive and less toxic hydroquinones forms (Atia et al., 2014). Mice lacking a functional NQO1 gene (NQO1-/-) were phenotypically indistinguishable and reproduced normally when compared to wild-type NQO1+/+ mice (Gaikwad et al., 2001). The livers of NQO1-/- mice were found to have significantly higher levels of triglycerides, lactate, pyruvate, and glucose. The livers of these mice had reduced glycogen reserve, significantly lower pyridine nucleotides levels and increased reduced/oxidized $\mathrm{NAD}(\mathrm{P}) \mathrm{H}: \mathrm{NAD}(\mathrm{P})$ ratio, compared to wild-type mice. These findings indicated that loss of NQO1 activity changed the in vivo redox status by increasing the concentration of $\mathrm{NAD}(\mathrm{P}) \mathrm{H}$. Consequently, this will lead to a reduction in pyridine nucleotide synthesis and reduced glucose and fatty acid metabolism. The altered metabolic processes as a result of redox changes would cause significant reduction in the amount of abdominal adipose tissue (Gaikwad et al., 2001).
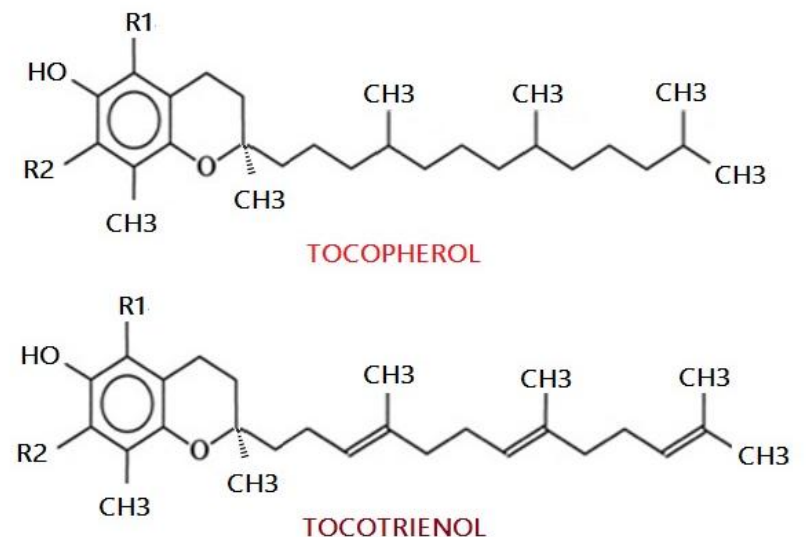

Fig. 1: Chemical structures of tocopherol and tocotrienol.

NQO1 expression increased in response to the production of reactive oxygen species (ROS) due to inflammation or xenobiotic exposure (Venugopal and Jaiswal, 1996). NQO1 expression was significantly increased while superoxide dismutase (SOD) activity was significantly reduced in advanced hepatocellular carcinoma (Moreira et al., 2015). These findings suggest that NQO1 acts directly as a superoxide anion scavenger, albeit less efficient than SOD (Siegel et al., 2004). Deficiency in NQO1 will result in additional loss of protection against oxidative stress, exposing cells to ROS attack. It had been postulated that the presence high SOD levels but low NQO1 levels in vivo would result in decreased clearance of superoxide anion, thus generating other ROS and worsening liver injury (Dinkova-Kostova and Talalay, 2010). In liver injury due to paracetamol poisoning and primary biliary cirrhosis, NQO1 protein expression and activity are significantly induced. It was hypothesized that increased NQO1 expression might represent a common response to liver injury with an oxidative stress component. Upregulation of NQO1 could represent an adaptive stress response to prevent further liver damage due to ROS attack (Aleksunes et al., 2006). Apart from affecting the liver, loss of NQO1 gene expression in NQO1-/mice resulted in myelogenous hyperplasia of bone marrow (Long et al., 2002). NQO1-/- mice also demonstrated benzene toxicity and increased sensitivity to skin carcinogenesis in response to benzo(a)pyrene and dimethylbenzanthracene (Long et al., 2000; Long et al., 2001; Bauer et al., 2003). NQO1-/- mice also showed lower levels of tumor suppressor protein p53 and decreased apoptosis in bone marrow and skin (Long et al., 2002; Iskander et al., 2004; Iskander et al., 2005). Loss of NQO1 has also been shown to cause hyperoxia induced lung injury in mice (Reddy et al., 2007). The antioxidant activities of vitamin $\mathrm{E}$ has been linked with the induction of several phase II antioxidant enzymes involved in cancer (Atia and Abdullah, 2014). These cytoprotective enzymes are crucial for cell defence by improving the removal of free radicals and thus, play a protective role against cancer and other diseases (Jaiswal, 2004; Kobayashi et al., 2004). NQO1 contains ARE (Antioxidant Response Element) sequence in the promoter region and therefore could potentially be regulated by nuclear factor (erythroid-derived 2)-like 2 (Nrf2) (Kaspar and Jaiswal, 2010). Nrf2 belongs to the basic leucine zipper transcription factor family, a member of the Cap 'n' Collar family of transcriptional proteins that binds to ARE leading to induction of many cytoprotective and antioxidant genes. Nrf2 binds to ARE and regulate expression and induction of NQO1 gene (Atia et al., 2014). Furthermore, researchers have recently associated the antioxidant activity of tocotrienols with Nrf2. Tocotrienols were also found to be successful in regulating Nrf2-related enzymes such as UDP-Glucuronyl transferase (UDP-GT), $\gamma$-glutamyl transferase (GGT) and glutathione S-transferase (GST) in breast cancer cells and mammary gland (Hsieh et al., 2010; Iqbal et al., 2003). However, no work has been done to see the effects of tocotrienols on NQO1 gene expression in mice liver. Therefore, in this study, NQO1 gene and protein expression levels were measured in the livers of mice supplemented with different doses of palm TRF.

\section{MATERIAL AND METHODS}

\section{Reagents}

Palm tocotrienol rich fraction (TRF) (Gold Tri.E 70) was purchased from Sime Darby Bioorganic (Kuala Lumpur, Malaysia) and contains $\alpha$-tocopherol at $159.5 \mathrm{mg} / \mathrm{g}, \alpha$-tocotrienol at $205.1 \mathrm{mg} / \mathrm{g}, \beta$-tocotrienol at $32.9 \mathrm{mg} / \mathrm{g}, \gamma$-tocotrienol at 249.8 $\mathrm{mg} / \mathrm{g}$ and $\delta$-tocotrienol at $119 \mathrm{mg} / \mathrm{g}$ (Lim et al. 2013). TRIzol reagent was purchased from Life Technologies (USA). iScript cDNA synthesis kit and iQ SYBR Green supermix (2X) kit were from Bio-Rad (USA). NQO1 primers were synthesized by Vivantis technologies (Oceanside, CA, USA). NQO1 rabbit polyclonal primary antibody and $\beta$-actin rabbit polyclonal primary antibody were purchased from Abcam Biotechnology (Cambridge, UK). Goat anti-rabbit IgG peroxidase secondary antibody were 
purchased from Santa Cruz Biotechnology (USA). Chemiluminescence Western blotting detection reagents were from GE Healthcare (Uppsala, Sweden). Nitrocellulose membrane and Ponceau $\mathrm{S}$ solution were purchased from Sigma-Aldrich (Seelze, Germany).

\section{Animals and treatment}

Male ICR white mice aged 10-12 weeks and weighing 25 to $30 \mathrm{~g}$ (provided by Universiti Kebangsaan Malaysia Animal Laboratory Unit) were used in this study. Mice were kept in clean polypropylene cages with food and water available ad libitum, and were placed in a well-ventilated room. Daily food intake and body weight were documented. Animals were treated with different doses of palm TRF (dissolved in corn oil). The mice were divided into 5 groups. The first group $(n=6)$ which comprise control mice, were only administered vehicle which is corn oil $(0.1 \mathrm{~mL})$. The second group $(n=6)$ consists of mice administered $200 \mathrm{mg} / \mathrm{kg}$ palm TRF $(0.1 \mathrm{~mL})$. The third group $(\mathrm{n}=6)$ consists of mice administered $500 \mathrm{mg} / \mathrm{kg}$ palm TRF $(0.1 \mathrm{~mL})$. The fourth group (n = 6) consists of mice administered $1000 \mathrm{mg} / \mathrm{kg}$ palm TRF (0.1 $\mathrm{mL})$.

The fifth group $(n=6)$ is the positive control group, where mice were administered butylated hydroxyanisole (BHA) at dose of $100 \mathrm{mg} / \mathrm{kg}$ dissolved in corn oil $(0.1 \mathrm{~mL})$. All the treatments were given via oral gavage for 14 days consecutively. Upon completion, mice were sacrificed via cervical dislocation. Liver tissues were excised, immediately frozen in liquid nitrogen, and stored at $-80{ }^{\circ} \mathrm{C}$ until further analysis. All experimental procedures involving animals were approved by the Universiti Kebangsaan Malaysia Animal Ethics Committee (UKMAEC), and the appoval code is: PP/FAR/2011/AZMAN/22-MARCH/361-MAY2011-MAY-2013.

\section{RNA Extraction and Quality Test}

Total RNA from the frozen tissues was isolated using TRIzol reagent, according to the manufacturer's instructions. Isopropyl alcohol (Sigma, USA) was added in each extraction step to precipitate the total RNA. Extracted total RNA pellet was then washed with $75 \%$ ethanol and dried before being dissolved in RNase free water. Total RNA was stored at $-80^{\circ} \mathrm{C}$ immediately after extraction. Concentration and purity of the extracted RNA were determined by NanoDrop spectrophotometer 2000c (Thermo Scientific, USA) at a wavelength of $260 \mathrm{~nm}$ (OD260). RNA with RNA integrity number (RIN) ranging from 7 to 10 and absorbance ratio of A260 to A280 ranging from 1.5 to 2.0 was used for cDNA synthesis.

\section{Reverse transcription}

Generation of cDNA from RNA was done using iScript cDNA synthesis kit (Bio-Rad, USA) according to the manufacturer's instructions. Briefly, total RNA (1 $\mu \mathrm{g})$ from each sample was added to a mixture of $4 \mu 1$ of $5 \mathrm{X}$ iScript reaction mix, $1 \mu \mathrm{l}$ of iScript reverse transcriptase, and $14 \mu \mathrm{l}$ of nuclease-free water in a total volume of $20 \mu \mathrm{l}$. The final reaction mix was kept at $25^{\circ} \mathrm{C}$ for $5 \mathrm{~min}, 42^{\circ} \mathrm{C}$ for $30 \mathrm{~min}$, and heated to $85^{\circ} \mathrm{C}$ for $5 \mathrm{~min}$ in a thermocycler (TC-412, Techne, Barloworld Scientific, UK). The cDNA was then used as a template for amplification by PCR.

\section{Quantitative real-time PCR}

Both forward and reverse primers for the genes of interest in this study were designed according to previous work (Kong et al., 2007; Leung et al., 2003) and synthesized by Vivantis Technologies (Oceanside, CA, USA). The primer sequences for our gene of interest are shown in Table 1. Real-time PCR was performed on the MiniOpticon cycler (Bio-Rad, USA) using iQ SYBR Green Supermix (2X) Kit (Bio-Rad, USA) in a total reaction volume of $20 \mu \mathrm{l}$ containing $1 \mu \mathrm{l}$ cDNA, $10 \mu \mathrm{l} \mathrm{SYBR}$ Green Mix $(2 \mathrm{X})$ and $500 \mathrm{nM}$ of each primers in order to detect NQO1 expression levels. All measurements were performed in triplicate and no-template controls (NTC) were incorporated onto the same set of PCR tubes to test for the contamination by any assay reagents. The thermocycling conditions were initiated at $95^{\circ} \mathrm{C}$ for $30 \mathrm{sec}$, followed by $40 \mathrm{PCR}$ cycles of denaturation at $95^{\circ} \mathrm{C}$ for $15 \mathrm{~s}$ and annealing / extension at $60^{\circ} \mathrm{C}$ for $30 \mathrm{sec}$. Melting curve was performed by the end of each cycle to confirm the specificity of the primers and the purity of the final PCR product. Threshold cycles were determined for each gene and quantification of templates was performed according to the relative standard curve method. The expression level of each target gene was given as relative amount normalized against GAPDH standard controls. Subsequently, agarose gel electrophoresis was performed to determine the reliability of the melting curve analysis and to confirm the size of the PCR product.

Table 1: Primer sequence for GAPDH and NQO1

\begin{tabular}{|c|c|c|c|}
\hline ة & $\begin{array}{l}\dot{z} \\
\dot{\ddot{z}}\end{array}$ & Primer sequence & $\dot{\dot{m}}$ \\
\hline GADPH & $\begin{array}{l}\text { NM_0 } \\
08084 \\
\end{array}$ & $\begin{array}{l}\text { F: 5'-GTGGAGTCTACTGGTGTCTTCA-3', } \\
\text { R: 5'-TTGCTGACAATCTTGAGTGAGT-3' }\end{array}$ & $\begin{array}{r}\text { Kong } e t \\
\text { al., } 2007\end{array}$ \\
\hline NQO1 & $\begin{array}{l}\text { NM_0 } \\
08706\end{array}$ & $\begin{array}{l}\text { F: 5'-GCATTGGCCACAATCCACCAG-3' } \\
\text { R: 5'-ATGGCCCACAGAGAGGCCAAA-3' }\end{array}$ & $\begin{array}{l}\text { Leung } e t \\
\text { al., } 2003 \\
\end{array}$ \\
\hline
\end{tabular}

\section{Western blotting}

Frozen tissue samples $(100 \mathrm{mg})$ were homogenized in 0.5 $\mathrm{ml}$ of RIPA buffer containing $10 \mu \mathrm{l}$ PMSF solution, $10 \mu \mathrm{l}$ sodium orthovanadate solution and $10 \mu \mathrm{l}$ protease inhibitor cocktail solution per $1 \mathrm{ml}$ of 1 X RIPA lysis buffer. Briefly, $0.1 \mathrm{~g}$ of frozen mouse liver was washed with phosphate buffer, and then lysed by using $0.5 \mathrm{ml}$ of RIPA lysis buffer [RIPA buffer and protease inhibitor cocktail (Santa Cruz Biotechnology, USA)] to extract the protein from cytosol. After centrifugation at $13,000 \times \mathrm{g}$ for $30 \mathrm{~min}$ at $4^{0} \mathrm{C}$, supernatants were collected and soluble protein concentrations were determined by the Lowry method using bovine serum albumin as a standard (Lowry et al., 1951). Gel electrophoresis was carried out using $10 \%$ Novex ${ }^{\circledR}$ Bis-Tris gels (Life Technologies, USA). Briefly, $100 \mu \mathrm{g}$ of protein loaded per well and subjected to electrophoresis using MOPS running buffer at $150 \mathrm{~V}$ for $60 \mathrm{~min}$. Wet transfer of proteins onto nitrocellulose 
membranes was made using a transfer buffer solution containing $30 \mathrm{mM}$ Tris- $\mathrm{HCl}, 200 \mathrm{mM}$ glycine, and $10 \%$ (v/v) methanol at $100 \mathrm{~V}$ for $1 \mathrm{~h}$. Following transfer, membranes were blocked for 20 min at room temperature in blocking solution containing $150 \mathrm{mM}$ $\mathrm{NaCl}, 3 \mathrm{mM} \mathrm{KCl}, 25 \mathrm{mM}$ Tris, $0.1 \%$ (v/v) Tween 20, 10\% non-fat dry milk powder ( $\mathrm{pH}$ 7.4). After blocking, membranes were incubated for another $1 \mathrm{~h}$ at room temperature with either primary polyclonal rabbit NQO1, or primary polyclonal rabbit anti-mouse actin. Antibodies specific to NQO1 and actin were used at dilutions of 1:10.000 and 1:5000, respectively. Subsequently, membranes were incubated with peroxidase-conjugated goat antirabbit IgG secondary antibody [1:5000 (v/v) dilution] for another $60 \mathrm{~min}$ and then blots were developed using the enhanced chemiluminescence method according to the manufacturer's instructions (GE Healthcare, Uppsala, Sweden). Bands were visualized using a gel documentation system (FluorChem FC2, Alpha Innotech, USA) and band densities were quantified using ImageJ tools software.

\section{Statistical analysis}

Data were expressed as mean \pm S.E.M. Significant differences between mean values of multiple groups were determined by one-way analysis of variance (ANOVA) with Tukey's HSD post-hoc test. Data not normally distributed was log transformed and analyzed using the Kruskal-Wallis one-way analysis of variance on ranks hypotheses. Statistical analysis was conducted using the SPSS software version 22. Differences were considered significant at $\mathrm{P}<0.05$.

\section{RESULTS}

Body weight gain and food intake after palm TRF treatment

To investigate whether different doses of palm TRF affect the body weight gain and food intake in control and experimental mice, body weight of mice in each group were recorded and food intake of each mice individually measured every two days till the end of the treatment period. Table 2 shows that in palm TRF treated groups, the body weight gain and food consumption were inhibited slightly by the administration of 1000 $\mathrm{mg} / \mathrm{kg} \mathrm{TRF}$ but not in 500 and $200 \mathrm{mg} / \mathrm{kg}$ palm TRF treated groups.

Table 2. Body weight and food intake of control and treated mice

\begin{tabular}{lccc}
\hline Groups & \multicolumn{2}{c}{ Body weight } & Food intake \\
\hline & Day 1 $(\mathbf{g})$ & Day 14 $(\mathbf{g})$ & $(\mathbf{g} /$ bw/day $)$ \\
\hline Control & $28.67 \pm 2$ & $33.33 \pm 2$ & $4.50 \pm 1$ \\
T200 & $27.67 \pm 2$ & $32.33 \pm 2$ & $4.37 \pm 2$ \\
T500 & $28.33 \pm 1$ & $30.33 \pm 1$ & $4.17 \pm 2$ \\
T1000 & $31.67 \pm 1$ & $30.33 \pm 2$ & $2.09 \pm 1$ \\
BHA & $30.00 \pm 1$ & $30.67 \pm 1$ & $4.93 \pm 1$ \\
\hline
\end{tabular}

T200, T500, T1000: Groups of mice treated with oral TRF at a daily dose of 200,500 and $1000 \mathrm{mg} / \mathrm{kg}$ body weight, respectively. Values are given as mean \pm SEM from six mice in each group. No statistical significance: control vs. treated groups (ANOVA).

However, the difference in body weight gain and food consumption were not statistically significant for all groups.
Administration of BHA alone did not show any significant alterations in those parameters and did not differ significantly from the normal control group.

\section{Confirmation of amplicon size and primer specificity of NQO1 mRNA}

The melting curve had exhibited the specificity of all primers used in this study, with each PCR product showing one specific melting temperature. The agarose gel electrophoresis used to ascertain the size of the PCR product in various treatment groups demonstrated that the PCR bands were specific and also were at the desired length [GAPDH, $137 \mathrm{bp}$ (predicted: $161 \mathrm{bp}$ ); NQO1, 172 bp (predicted: 200 bp)]. The standard curve drawn with $\mathrm{Cq}$ value versus log RNA starting quantity showed the PCR reactions for NQO1 and GAPDH were at $108.8 \%$ and $98.3 \%$ efficiency and correlation coefficient of 0.961 , and 0.991 respectively (Figure 2).
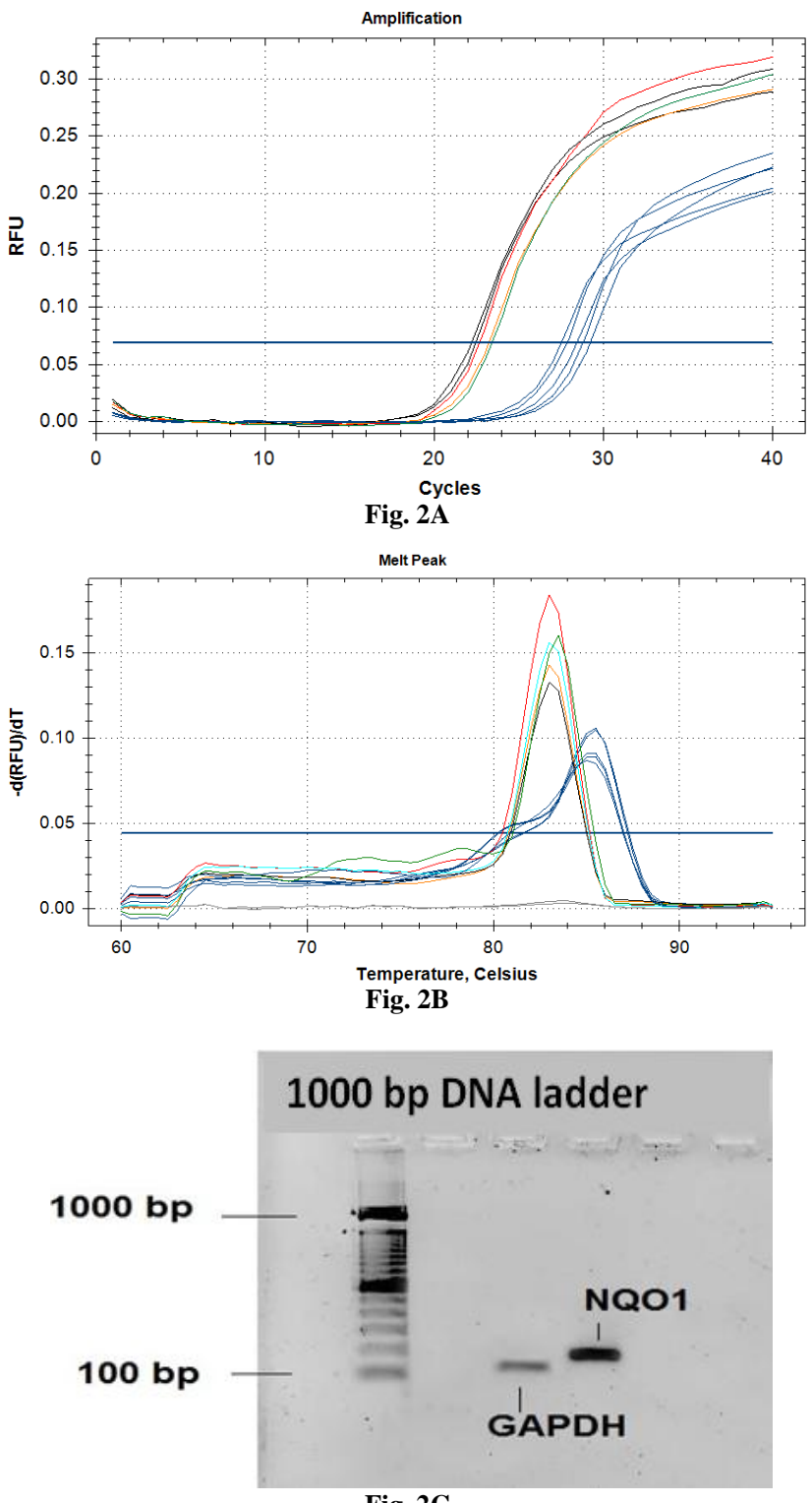

Fig. 2C 


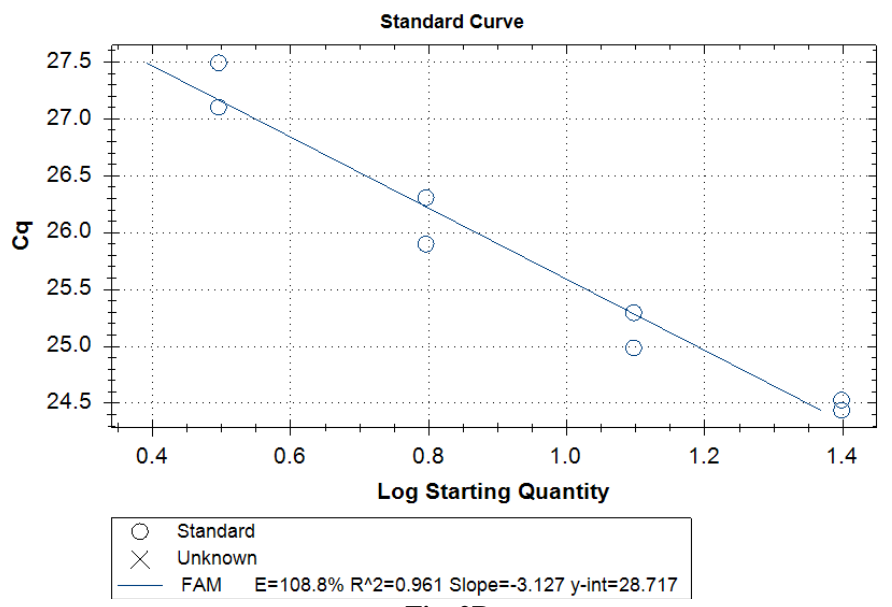

Fig. 2D

Fig. 2: NQO1 and GAPDH mRNA expressions. The Ct value showed the expression level of NQO1 and GAPDH mRNA (A). The melting curve demonstrated all PCR products had the specific melting temperature (B). Agarose gel electrophoresis confirmed the size of all the PCR products generated $(\mathrm{C})$. The standard curve showed the threshold cycle $(\mathrm{Ct})$ versus concentration of the total RNA from serial dilution (D).

\section{Liver NQO1 gene expression}

To examine the effect of palm TRF on NQO1 mRNA, mice were fed with several doses of palm TRF (200, 500, 1000 $\mathrm{mg} / \mathrm{kg}$ ) in the presence of vehicle-treated control mice (fed corn oil) and a positive control group administered BHA at dose 100 $\mathrm{mg} / \mathrm{kg}$ for 14 days. After 14 days of treatment the mice were sacrificed and NQO1 mRNA expression in the liver was measured using quantitative real-time PCR. As shown in Figure 3, palm TRF at the concentrations of 200,500 , and $1000 \mathrm{mg} / \mathrm{kg}$ caused a significant concentration-dependent increase in fold change of NQO1 expression levels [1.3-, 1.7-, and 2.6-fold respectively, as compared to controls; $(\mathrm{p}<0.05)]$. Mice treated with BHA (100 $\mathrm{mg} / \mathrm{kg}$ ) also showed significant increase in fold change of NQO1 mRNA level by 2.9 -fold, compared to controls.

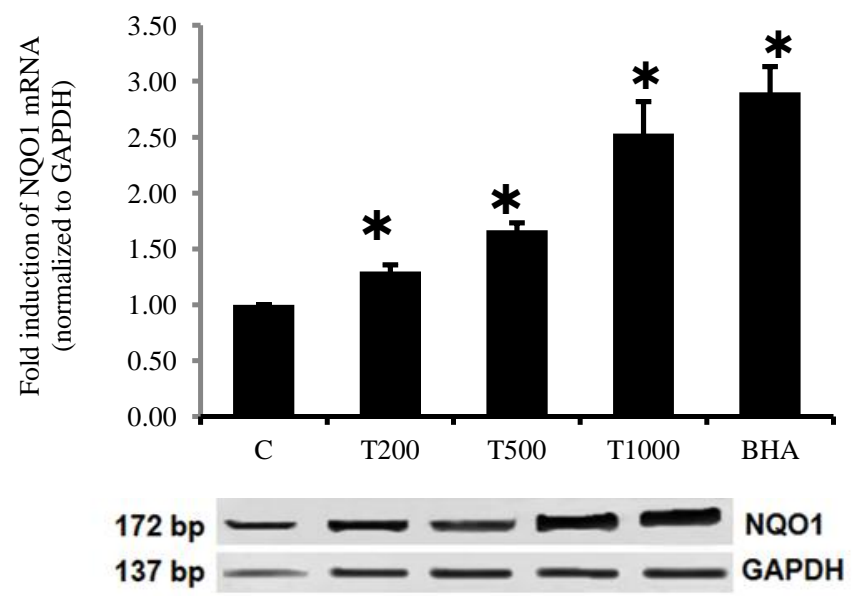

Fig. 3: Concentration-dependent effect of palm TRF on NQO1 mRNA. Data is expressed relative to controls as mean \pm S.E.M. Asterisks (*) indicate statistically significant difference from the control group $(\mathrm{p}<0.05)$. Agarose gel electrophoresis was also performed to determine the reliability of the melting curve analysis and to confirm the size of the PCR product. T200, TRF at dose $200 \mathrm{mg} / \mathrm{kg}$; T500, TRF at dose $500 \mathrm{mg} / \mathrm{kg}$; T1000, TRF at dose $1000 \mathrm{mg} / \mathrm{kg}$; C, control mice; BHA, butylated hydroxyanisole.

\section{Liver NQO1 protein expression}

In agreement with the NQO1 mRNA results, palm TRF at the concentrations of 200,500 , and $1000 \mathrm{mg} / \mathrm{kg}$ significantly increased liver NQO1 protein levels by 1.3-, 1.5-, and 1.9-fold respectively, compared to controls $(\mathrm{p}<0.05)$. Mice treated with BHA $(100 \mathrm{mg} / \mathrm{kg})$ increased NQO1 protein level by 2.2 -fold $(\mathrm{p}<$ 0.05), compared to controls (Figure 4).

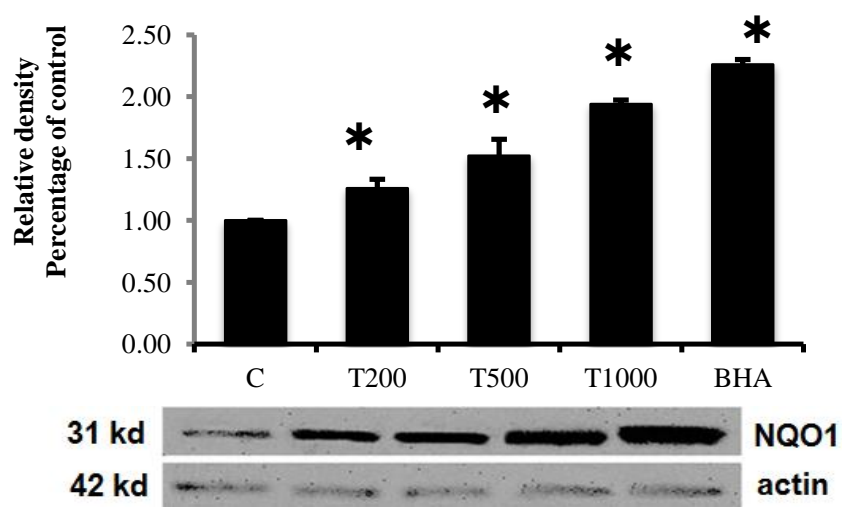

Fig. 4: Effect of different doses of palm TRF on NQO1 protein level. The graph represents the average optical density ( \pm S.E.M.) of bands from three different biological replicates of Western blot experiments as a percentage of control. (*) P < 0.05 compared to the control. T200, TRF at dose $200 \mathrm{mg} / \mathrm{kg}$; T500, TRF at dose $500 \mathrm{mg} / \mathrm{kg}$; T1000, TRF at dose $1000 \mathrm{mg} / \mathrm{kg}$; C, control mice; BHA, butylated hydroxyanisole.

\section{DISCUSSION}

Previous in vitro study has shown that pre-treatment with $\alpha$-tocopherol supplementation produced significant increase in NQO1 expression level in human retinal pigment epithelial cells (Feng et al., 2010). While a number of studies explored the effect of tocopherol on NQO1 gene expression, there has not been any study on NQO1 gene expression in mouse liver after tocotrienol treatment. In this current work, the effects of different doses of palm TRF supplementation on NQO1 gene and protein levels in mice livers have been examined. Mice were treated with several different concentrations of palm TRF $(200,500,1000 \mathrm{mg} / \mathrm{kg}$ ) for 14 days in presence of BHA-treated mice as positive indicator and vehicle-treated mice as controls. We have documented a significant concentration-dependent increase in fold change of NQO1 expression levels in the palm TRF treated mice compared to controls.

A group of researchers had previously investigated the effects of $\alpha$-tocopherol on phase II enzymes and its protective effects on acrolein-induced toxicity in human retinal pigment epithelial (RPE) cell line, ARPE-19 (Feng et al., 2010). They discovered that pre-treatment with $\alpha$-tocopherol activated the Nrf2/Keap1 pathway by increasing Nrf2 expression and inducing its translocation to the nucleus. Consequently, the expression and / or activity of many phase II enzymes (such as NQO1) were found to be increased (Feng et al., 2010). Another study reported that the mRNA and protein expressions of NQO1 were induced in TRAMP-C1 cells treated with $30 \mathrm{mmol} / \mathrm{L}$ of $\gamma$-tocopherol-rich mixture of tocopherols compared with the control cells (Huang et 
al., 2012). However, a different group of researchers found out that NQO1 expression was not affected by $\alpha$-, $\gamma$ - and $\delta$-tocotrienols treatment in MCF-7 cells, but the expression of NQO2 was remarkably induced by tocotrienols (Hsieh et al., 2010). Additionally, the expression levels of NQO1 in TRAMP mice remained unchanged after treatment with $0.1 \% \quad \gamma$-tocopherolenriched mixed tocopherol diet (Barve et al., 2009). In contrast, a nine-week treatment of vitamin $\mathrm{E}$ deficient diet to male rats resulted in higher NQO1 activities (De Cabo et al., 2006).

Reports pertaining to vitamin E and NQO1 gene expression have been scarce. However, other nutrients and vitamins have been shown to influence NQO1 gene expression. One study explored the role of NQO1 in prevention of $17 \beta$ estradiol (E2)-induced breast cancer by antioxidants vitamin $\mathrm{C}$ (Vit C) or BHA or E2 metabolic inhibitor ANF in female ACI rats. It was shown that NQO1 activity was significantly decreased in mammary tumours and mammary tissues of rats treated with E2 compared to age-matched control mammary tissue. However, NQO1 enzyme activity was significantly increased in mammary tissue of rats undergoing treatment with $\mathrm{BHA}, \mathrm{BHA}+\mathrm{E} 2$, Vit $\mathrm{C}$ or Vit C + E2 for 240 days, compared to age-matched control mammary tissue (Singh et al., 2012). Increased NQO1 activity in kidneys, lungs and the mucosa of the upper small intestine was found in mice treated with vitamin $\mathrm{E}$ at a concentration of $7.5 \mathrm{~g} / \mathrm{kg}$ for 14 days (Benson et al., 1980). Other biochemical studies have elucidated that NQO1 activity is induced by a wide range of chemicals including polycyclic aromatic hydrocarbons, azo dyes and phenolic antioxidants (Dinkova Kostova et al., 2004).

NQO1 is a key enzyme involved in cellular defence against electrophilic and reactive forms of oxygen (Nioi and Hayes, 2004). NQO1 is believed to be involved in the the metabolic detoxification of quinones and could therefore affords protection against chemically induced oxidative stress and cancer (Nioi and Hayes, 2004; Girolami et al., 2008). NQO1 preserve certain endogenous antioxidants in their reduced and active forms, particularly ubiquinone and $\alpha$-tocopherol-quinone, two essential lipid-soluble antioxidants which are substrates for NQO1 in vitro (Bello et al., 2003). Moreover, besides its catalytic role in reduction of quinones, NQO1 has been found to scavenge superoxide directly, and this activity could bring extra protection and could be particularly efficient in tissues with low level of SOD enzyme expression. Thus, in cardiovascular cells, where expression level of SOD is relatively low and that of NQO1 is high, induction of NQO1 was revealed to correlate with elevating superoxide scavenging activity, while its suppression resulted in decreased superoxide scavenging activity (Zhu et al., 2007). In human and rodent tissues, NQO1 is one of the major genes continuously and essentially inducible among the members of the family of antioxidant genes. NQO1 is significantly expressed in many tumour tissues such as breast, lung, liver, colon, and pancreatic tissues, and its expression induced in response to several xenobiotics and antioxidants (Suh et al., 2004).

Antioxdant Response Element (ARE) activation by Nrf2 is required for expression and coordinated induction of NQO1 and other phase II detoxification genes (Dinkova-Kostova and Talalay, 2010). In our study, tocotrienol was able to increase hepatic NQO1 gene and protein levels in wild type $(\mathrm{Nrf} 2+/+)$ mice. It had been suggested in previous studies that an increase in NQO1 gene expression occurs in response to xenobiotic exposure in mouse liver hepatoma (Hepa-1) cells (Venugopal and Jaiswal, 1996). Chemicals such as BHA and sulforaphane had been shown to induce NQO1 in the liver of wild type $(\mathrm{Nrf} 2+/+)$ mice but not in the liver of Nr2-null (Nrf2-/-) mice (Luo et al., 2015a, 2015b). Therefore, with the use of Nr2-null (Nrf2-/-) mice, NQO1 expression and induction in the liver have conclusively been found to be Nrf2-dependent (Luo et al., 2015a, 2015b).

Treatment of experimental animals with chemicals that generate a mild oxidative stress in the liver but does not cause any obvious liver pathology, have been shown to induce NQO1 and other drug-metabolising/antioxidant enzymes genes. Consequently, the increased antioxidant and detoxication capability could provide protection (albeit for a period of time) against subsequent exposure to oxidants, harmful chemicals and potential carcinogens (Nioi and Hayes, 2004). This therapeutic strategy to reduce the risk of liver cancer (and other types of cancers) is defined as chemoprevention, and has led to the development of several screening assays to identify novel compounds that could potentially inhibit the carcinogenesis process in the liver or other organs (Surh, 2003). One useful screening approach utilises the induction of NQO1 enzyme activity in mouse Hepa-1c1c7 cell line as its end-point (Fahey et al., 2004). Through this assay, various chemicals (diphenols, quinones, dithiolethiones, hydroperoxides, peroxides, Michael reaction acceptors) were shown to induce NQO1 enzyme activity in mouse liver Hepa-1c1c7 cells (Dinkova-Kostova et al., 2004). Other studies also utilised NQO1 induction in mouse liver Hepa$1 \mathrm{c} 1 \mathrm{c} 7$ cells to screen phytochemicals found in natural products as potential anticancer agents. The results of these studies showed that chemicals derived from natural products such as alkyl and alkenyl sulfides, brassinin derivatives, carotenoids, curcumin derivatives and flavonoids were able to induce mouse liver NQO1 (Nioi and Hayes, 2004). Induction of NQO1 is not unique to mouse Hepa-1c1c7 hepatoma cells but is also observed in nontransformed rat liver RL-34 cell lines (Nioi et al., 2003).

As for the potential benefit our study, we postulate that the increase in NQO1 expression after subscribing to TRF supplementation for a period of time can protect the liver from excessive injury by preventing the accumulation of poisonous toxicants and their metabolites, in circumstances such as accidental ingestion aflatoxin-contaminated food, excessive alcohol intake, and chronic oral administration of over-the-counter (OTC) drugs that could potentially cause injury to the liver such as paracetamol and NSAIDs, for example. Previous studies had associated the antioxidant activities of tocotrienols with the ARENrf2 pathway (Hsieh et al., 2010; Iqbal et al., 2003). Therefore, in our study, it is postulated that the activation of ARE-Nrf2 signaling pathway by tocotrienols in TRF extract might be responsible for the up-regulation of NQO1 in mice liver. Our data 
may bring in some additional information on the role for Nrf2 in the expression of NQO1 in various tissues by TRF. Future studies on the effects of TRF on other phase II antioxidant enzymes may be important in order to boost palm oil-derived TRF role as a possible cost-effective chemopreventive agent.

\section{CONCLUSION}

In summary, we have reported for the first time that palm TRF treatment increased NQO1 gene and protein levels in mice liver dose dependently, with the highest expression seen with mice treated with $1000 \mathrm{mg} / \mathrm{kg} \mathrm{TRF}$, followed by 500 and $200 \mathrm{mg} / \mathrm{kg}$ respectively. Therefore, consumption of TRF could potentially prove to be beneficial in preventing liver toxicity and could also potentially be a cost-effective cancer chemoprevention measure.

\section{Conflicts of interests}

The authors reported no conflict of interests.

\section{ACKNOWLEDGMENTS}

This work is funded by the National University of Malaysia Grant FF-176-2013 and UKM-GGPM-TKP-051-2010.

\section{AUTHOR CONTRIBUTIONS}

Ahmed Atia conducted the study and drafted the manuscript. Nadia Alrawaiq was involved in lab work and data analysis. Azman Abdullah obtained funding, supervised the project and provided critical review and final approval for the manuscript. All authors have approved the final article.

\section{REFERENCES}

Aleksunes LM, Goedken M, Manautou JE. Up regulation of $\mathrm{NAD}(\mathrm{P}) \mathrm{H}$ quinineoxidoreductase 1 during human liver injur y. World J Gastroenterol, 2006; 12:1937-40.

Atia A, Abdullah A. Tocotrienols: molecular aspects beyond its antioxidant activity. JMRP, 2013; 2:246-50.

Atia A, Abdullah A. Tocotrienols: the other half of natural vitamin E. RJPBCS, 2014; 5:533-43.

Atia A, Alrawaiq N, Abdullah A. A review of $\mathrm{NAD}(\mathrm{P}) \mathrm{H}$ : quinone oxidoreductase 1 (Nqo1); a multifunctional antioxidant enzyme. J App Pharm Sci, 2014; 4:118-22.

Barve A, Khor TO, Nair S, Reuhl K, Suh N, Reddy B, Newmark H, Kong AN. Gamma-tocopherol-enriched mixed tocopherol diet inhibits prostate carcinogenesis in TRAMP mice. Int J Cancer, 2009; 124:1693-99.

Bauer AK, Faiola B, Abernethy DJ, Marchan R, Pluta LJ, Wong VA, Roberts K, Jaiswal AK, Gonzalez FJ, Butterworth BE, Borghoff S, Parkinson H, Everitt J, Recio L. Genetic susceptibility to benzene-induced toxicity: role of NADPH:quinone oxidoreductase 1. Cancer Res, 2003; 63:929-35.

Bello RI, Kagan VE, Tyurin V, Navarro F, Alcaín FJ, Villalba JM. Regeneration of lipophilic antioxidants by $\mathrm{NAD}(\mathrm{P}) \mathrm{H}$ :quinone oxidoreductase 1. Protoplasma, 2003; 221:129-35.

Benson AM, Hunkeler MJ, Talalay P. Increase of NAD(P)H: quinone reductase by dietary antioxidants: possible role in protection against carcinogenesis and toxicity. Proc Natl Acad Sci USA, 1980; 77:5216-20.

Colombo ML. An update on vitamin E, tocopherol and tocotrienol-perspectives. Molecules, 2010; 15:2103-13.
De Cabo R, Burgess JR, Navas P. Adaptations to oxidative stress induced by vitamin $\mathrm{E}$ deficiency in rat liver. J Bioenerg Biomembr, 2006; 38:309-17.

Dinkova-Kostova AT, Fahey JW, Talalay P. Chemical structures of inducers of nicotinamide quinone oxidoreductase 1 (NQO1). Methods Enzymol, 2004; 382:423-48.

Dinkova-Kostova AT, Talalay P. NAD(P)H:quinone acceptor oxidoreductase 1 (NQO1), a multifunctional antioxidant enzyme and exceptionally versatile cytoprotector. Arch Biochem Biophys, 2010; 501:116-23.

Fahey JW, Dinkova-Kostova AT, Stephenson KK, Talalay P. The "Prochaska" microtitre plate bioassay for inducers of NQO1. Methods Enzymol, 2004; 382:243-58.

Gaikwad A, Long DJ II, Stringer JL, Jaiswal AK. In vivo role of $\mathrm{NAD}(\mathrm{P}) \mathrm{H}$ :quinone oxidoreductase 1 (NQO1) in the regulation of intracellular redox state and accumulation of abdominal adipose tissue. $\mathrm{J}$ Biol Chem, 2001; 276:22559-64.

Feng Z, Liu Z, Li X, Jia H, Sun L, Tian C, Jia L, Liu J. AlphaTocopherol is an effective Phase II enzyme inducer: Protective effects on acrolein-induced oxidative stress and mitochondrial dysfunction in human retinal pigment epithelial cells. J Nutr Biochem, 2010; 21:122231.

Girolami F, Abbadessa G, Racca S, Spaccamiglio A, Piccione F, Dacasto M, Carletti M, Gardini G, Di Carlo F, Nebbia C. Timedependent acetylsalicylic acid effects on liver CYP1A and antioxidant enzymes in a rat model of 7,1dimethylbenzanthracene(DMBA)-induced mammary carcinogenesis. Toxicol Lett, 2008; 181:87-92.

Hsieh TC, Elangovan S, Wu JM. Differential suppression of proliferation in MCF-7 and MDA-MB-231 breast cancer cells exposed to alpha-, gamma- and delta-tocotrienols is accompanied by altered expression of oxidative stress modulatory enzymes. Anticancer Res, 2010 30: 4169-76.

Huang Y, Khor TO, Shu L, Saw CL, Wu TY, Suh N, Yang CS, Kong AN. A $\gamma$-tocopherol-rich mixture of tocopherols maintains Nrf2 expression in prostate tumors of TRAMP mice via epigenetic inhibition of CpG methylation. J Nutr, 2012; 142:818-23.

Iqbal J, Minhajuddin M, Beg ZH. Suppression of 7,12 dimethylbenz[alpha]anthracene induced carcinogenesis and hypercholesterolemia in rats by tocotrienol-rich fraction isolated from rice bran oil. Eur J Cancer Prev, 2003; 12:447-53.

Iskander K, Gaikwad A, Paquet M, Long DJ 2nd, Brayton C, Barrios R, Jaiswal AK. Lower induction of p53 and decreased apoptosis in NQO1-null mice leads to increased sensitivity of chemical-induced skin carcinogenesis. Cancer Res, 2005; 65:2054-58.

Iskander K, Paquet M, Brayton C, Jaiswal AK. Deficiency of NRH:quinone oxidoreductase 2 increases susceptibility to 7,12dimethybenz(a)anthracene and benzo(a)pyrene-induced skin carcinogenesis. Cancer Res, 2004; 64:5925-28.

Jaiswal AK. Regulation of antioxidant response elementdependent induction of detoxifying enzyme synthesis. Methods Enzymol, 2004; 378:221-38

Kobayashi A, Ohta T, Yamamoto M. Unique function of the Nrf2-Keap1 pathway in the inducible expression of antioxidant and detoxifying enzymes. Methods Enzymol, 2004; 378:273-86.

Kong L, Tanito M, Huang Z, Li F, Zhou X, Zaharia A, Yodoi J, McGinnis JF, Cao W. Delay of photoreceptor degeneration in tubby mouse by sulforaphane. J Neurochem, 2007; 101:1041-52.

Leung L, Kwong M, Hou S, Lee C, Chan JY. Deficiency of the Nrf1 and Nrf2 Transcription Factors Results in Early Embryonic Lethality and Severe Oxidative Stress. J Biol Chem, 2003; 278:48021-29.

Lim JJ, Ngah WZ, Mouly V, Abdul Karim N. Reversal of myoblast aging by tocotrienol rich fraction post treatment. Oxid Med Cell Longev, 2013; Article ID 978101 (doi:10.1155/2013/978101).

Ling MT, Luk SU, Al-Ejeh F, Khanna KK. Tocotrienol as a potential anticancer agent. Carcinogenesis, 2012; 33:233-39.

Long DJ II, Gaikwad A, Multani A, Pathak S, Montgomery CA, Gonzalez FJ, Jaiswal AK. Disruption of the $\mathrm{NAD}(\mathrm{P}) \mathrm{H}$ :quinone oxidoreductase 1 (NQO1) gene in mice causes myelogenous hyperplasia. Cancer Res, 2002; 62:3030-36. 
Long DJ, Waikel RL, Wang XJ, Roop DR, Jaiswal AK. $\mathrm{NAD}(\mathrm{P}) \mathrm{H}$ :quinone oxidoreductase 1 deficiency and increased susceptibility to 7,12-dimethylbenz[a]-anthracene-induced carcinogenesis in mouse skin. J Natl Cancer Inst, 2001; 93: 1166-70.

Long DJ II, Waikel RL, Wang X, Perlaky L, Roop DR, Jaiswal AK. (2000): $\mathrm{NAD}(\mathrm{P}) \mathrm{H}$ :quinone oxidoreductase 1 deficiency increases susceptibility to benzo(a)pyrene-induced mouse skin carcinogenesis. Cancer Res, 2002; 60:5913-15.

Lowry OH, Rosebrough NJ, Farr AL, Randall RJ. Protein measurement with the Folin phenol reagent. J Biol Chem, 1951; 193:26575.

Luo L, Chen Y, Wu D, Shou J, Wang S, Ye J, Tang X, Jun Wang X. Differential expression patterns of Nqo1, AKR1B8 and Ho-1 in the liver and small intestine of C57BL/6 mice treated with sulforaphane. Data Brief, 2015a; 5:416-23.

Luo L, Chen Y, Wu D, Shou J, Wang S, Ye J, Tang X, Wang XJ. Butylated hydroxyanisole induces distinct expression patterns of Nrf2 and detoxification enzymes in the liver and small intestine of C57BL/6 mice. Toxicol Appl Pharmacol, 2015b; 288:339-48.

Moreira AJ, Rodrigues G, Bona S, Cerski T, Marroni C, Muriz J, Gonzalez-Gallego J, Marroni N. Oxidative Stress and Cell Damage in a Model of Precancerous Lesions and Advanced Hepatocellular Carcinoma in Rats. Toxicol Rep, 2015; 2:333-40.

Niki E. Evidence for beneficial effects of vitamin E. Korean J Intern Med, 2015; 30:571-9.

Nioi P, McMahon M, Itoh K, Yamamoto M, Hayes JD. Identification of a novel Nrf2-regulated antioxidant response element (ARE) in the mouse $\mathrm{NAD}(\mathrm{P}) \mathrm{H}$ :quinone oxidoreductase 1 gene: reassessment of the ARE consensus sequence. Biochem J, 2003; 374:33748.

Nioi $\mathrm{P}$, Hayes JD. Contribution of $\mathrm{NAD}(\mathrm{P}) \mathrm{H}$ : quinone oxidoreductase 1 to protection against carcinogenesis, and regulation of its gene by the Nrf2 basic-region leucine zipper and the arylhydrocarbon receptor basic helix-loop-helix transcription factors. Mutat Res, 2004; 555:149-71.

Reddy AJ, Cho HY, Walters DM, Kleeberger SR. Knockout of the $\operatorname{NAD}(\mathrm{P}) \mathrm{H}$ :quinone oxidoreductase 1 gene increases susceptibility to hyperoxia in mice. Chest, 2007; 132:564b.
Siegel D, Gustafson DL, Dehn DL, Han JY, Boonchoong P, Berliner LJ, Ross D. NAD(P)H:quinone oxidoreductase 1: role as a superoxide scavenger. Mol Pharmacol, 2004; 65:1238-47.

Singh B, Bhat NK, Bhat HK. Induction of NAD $(\mathrm{P}) \mathrm{H}$-quinone oxidoreductase 1 by antioxidants in female ACI rats is associated with decrease in oxidative DNA damage and inhibition of estrogen-induced breast cancer. Carcinogenesis, 2012; 33:156-63.

Suh JH, Shenvi SV, Dixon BM, Liu H, Jaiswal AK, Liu RM, Hagen TM. Decline in transcriptional activity of Nrf2 causes age-related loss of glutathione synthesis, which is reversible with lipoic acid. Proc Natl Acad Sci USA, 2004; 101: 3381-6.

Surh Y-J. Cancer chemoprevention with dietary phytochemicals. Nat Rev Cancer, 2003; 3:768-80.

Valk EE, Hornstra G. Relationship between vitamin E requirement and polyunsaturated fatty acid intake in man: A review. Int $\mathrm{J}$ Vitam Nutr Res, 2000; 70:31-42.

Vasanthi HR, Parameswari RP, Das DK. Multifaceted role of tocotrienols in cardioprotection supports their structure: function relation. Genes Nutr, 2012; 7:19-28.

Venugopal R, Jaiswal AK. Nrf1 and Nrf2 positively and c-Fos and Fra1 negatively regulate the human antioxidant response elementmediated expression of $\mathrm{NAD}(\mathrm{P}) \mathrm{H}$ :quinone oxidoreductase1gene. Proc Natl Acad Sci USA, 1996; 93:14960-65.

Zhu H, Jia Z, Mahaney JE, Ross D, Misra HP, Trush MA, Li Y. The highly expressed and inducible endogenous $\mathrm{NAD}(\mathrm{P}) \mathrm{H}$ :quinone oxidoreductase 1 in cardiovascular cells acts as a potential superoxide scavenger. Cardiovasc Toxicol, 2007; 7: 202-11.

\section{How to cite this article:}

Atia A, Alrawaiq N, Abdullah A. Tocotrienol-rich Palm Oil Extract Induces NAD(P)H:quinone Oxidoreductase 1 (NQO1) Expression in Mice Liver. J App Pharm Sci, 2016; 6 (08): 127-134. 